\title{
LAST NIGHT I DREAMED OF PEACE: AN EXTRAORDINARY DIARY OF COURAGE FROM THE VIETNAM WAR
}

\section{Dang Thuy Tram (Translated by Andrew X Pham)}

London: Three Rivers Press

2008, 225 pages

ISBN 9781846040764

Many people's view about war and its impact was changed by a woman named Dang Thuy Tram. Her diaries, which she kept as a practicing medical doctor during the Vietnam War, were published some forty odd years after her death. The diaries contain personal accounts of how she viewed and experienced the Vietnam War. The publication of the diaries made headlines in the non-English reading world.

Dang Thuy Tram was born in the north of Vietnam where she also grew up. She developed an intense interest in medical studies. Her father's profession as a surgeon partially inspired Dang Thuy Tram to study medicine after secondary school. After her studies, she was assigned to work in Quang Ngai Province, south of the disputed borders between North and South Vietnam. With an ongoing civil war mostly due to foreign interference (the USA saw large parts of Asia as an important sphere of influence). The young Thuy found herself in a world with everchanging challenges. Areas of Quang Ngai Province, mountainous, tropical and marshy as it was, became a focal point of armed resistance as it was an ideal hideout for guerrillas since the French colonial era.

The introduction of the book suggests that Dang Thuy Tram was forced to serve in the south of Vietnam because of a man who was popularly known by the nom du guerre of M. The man's real name was Khuong The Hung, and he was a family friend of the Trams. Unfortunately, the knowledge of what happened between

Scientia Militaria, South African Journal of Military Studies, Vol 42, Nr 1, 2014, pp. 136-138. doi : $10.5787 / 42-1-1086$
Dang Thuy Tram and Khuong is unknown as Dang Thuy Tram's first diary could not be located. It is said that Dang Thuy Tram realised that $\mathrm{M}$ did not love her as much as she loved him. However, the relationship had a formative 
influence on Dang Thuy Tram.

Dang Thuy Tram arrived in Quang Ngai Province on 8 April 1968. Her medical duties were carried out clandestinely and permanently on the move in hidden hospitals and medical posts for wounded soldiers and the endless stream of civilian victims in need of medical attention. Dang Thuy Tram had to perform her duties with scant resources. Frequently the liberation army would recall those who could still carry on fighting and leave her with the dying soldiers. It was such conditions which drove her to penning down her emotions and experiences. Her dairies offer intimate insight into the loneliness, doubt, fear and determination in witnessing a ferocious war at such close range. Gunshots and mortar shelling were just a stone's throw away, and she often had a longing for the safer and happier times she once shared with her family. When she was killed by an American patrol, all that was left was a Sony radio, a notebook with drawings of the wounds she had treated, a rice ledger and her diaries, which were returned to her family over 35 years after the war. Dang Thuy Tram was killed on 22 June 1970 when the patrol opened fire on them observing her and other people walking on a trail towards where the Americans had deployed.

The diaries of Dang Thuy Tram brought to the fore an unexpected spectacle with which to view the war and its effects. Usually tales of war are told through the eyes of soldiers or commanders. Moreover, the Vietnam War is recounted in numerous publications favouring the side of the Western aggressors. The diaries of Dang Thuy Tram expose the public to war as told by a young doctor about the people affected by the war and whose dreams were to wake up in a world of peace. On reading her diaries, one realises that she was no less a casualty of the war than her patients. An idealist at heart, her diaries illuminate a different perspective to war. Her battle to fight was not at the forefront of the firing line, but behind the enemy lines and, most importantly, with herself and her patients for survival. Dang Thuy Tram was, just like any other soldier, one can imagine, struggling to keep going in the midst of battle. Once she wrote, "To live is to face the storms and not to cower before them. Stand up, then, oh, Thuy! Even when the rain and gale are rising, even when tears have flowed in torrents, keep your spirit high." Dang Thuy Tram did not live to see 30 April 1973 when the war ended and the last Marines to protect the USA Embassy were lifted by helicopter. Fifteen years of war had ended.

The only weakness, which cannot be blamed on anyone, is that the book only reflects the events that Dang Thuy Tram experienced during the last year as her first diaries did not survive the war. Needless to say, it would have been of great 
historical value if all her diaries had survived in order to relate the entire story about a young doctor with first-hand experience of the Vietnam War.

Lesedi Dawn Rakumakoe, Postgraduate student in Security and Africa Studies, Faculty of Military Science, (Military Academy), Stellenbosch University. 